AGRO EKONOMI, Vol 29, Issue 2, December 2018, Page. 287-298

DOI : http://doi.org/10.22146/ae.36442

ISSN 0215-8787 (print), ISSN 2541-1616 (online)

Available at https://jurnal.ugm.ac.id/jae/

\title{
RICE MARKETING EFFICIENCY IN SRAGEN REGENCY
}

\section{Efisiensi Pemasaran Beras Di Kabupaten Sragen}

\author{
Amalia Nadifta Ulfa ${ }^{1}$, Masyhuri ${ }^{2}$ \\ ${ }^{1}$ Master Student of Agricultural Economics, Faculty of Agriculture, \\ Universitas Gadjah Mada \\ ${ }^{2}$ Faculty of Agriculture, Universitas Gadjah Mada \\ Jl. Flora No. 1 Bulaksumur, Yogyakarta \\ amalia.nadifta@gmail.com
}

Submitted: 28 June 2018; Revised: 19 October 2018; Accepted: 23 November 2018

\begin{abstract}
This study aims to determine the channels, margins, and the level of marketing efficiency of rice in Sragen used monopoly index (MPI) and market integration. This study used primary data obtained from direct interview, and secondary data obtained from related institutions. The rice marketing channels were obtained by surveys and interviews with the snowball sampling methods. The data were analyzed using marketing channels ranging from rice mills to consumers. The results show that there are four marketing channels of rice with the most on channels 3 about $53.3 \%$. The first channel is the shortest channel with the lowest marketing margin, but it is inapporopiate to conclude that the first channel is the most efficient channel. The highest marketing margin of rice marketing channels is at the medium/large rice mills, while the lowest is at the wholesalers. The MPI value of collecting traders is $2.00 ; 2.32$ for medium/large rice mills; wholesalers is 1.47 ; and 1.75 for retailers. The comparison of MPI in each marketing institution shows that medium/large rice mill dominate rice marketing in Sragen. The correlation analysis of 0.952 means a "very strong" correlation between price at rice mills level and price at consumers level. Based on the marketing efficiency analysis using MPI and market integration, it shows that marketing of rice in Sragen has been integrated and efficient. The research recommends further analysis of rice marketing in other areas for rice marketing for rice mills or rice traders in Sragen.
\end{abstract}

Keywords: Marketing Efficiency, Market Integration, Monopoly Index, Rice.

Ulfa, A.N. \& Masyhuri (2018) Rice Marketing Efficiency in Sragen Regency. Agro Ekonomi, 29(2) $: 287-298$

\section{INTISARI}

Penelitian ini bertujuan untuk mengetahui saluran, margin, serta tingkat efisiensi pemasaran beras di Kabupaten Sragen menggunakan monopoli indeks (MPI) dan integrasi pasar. Data penelitian menggunakan data primer melalui wawancara langsung, dan data sekunder dari instansi terkait. Saluran pemasaran beras diperoleh melalui survei dan wawancara dengan metode snowball sampling. Analisis saluran pemasaran dimulai dari penggilingan padi kecil sampai kosumen akhir. Hasil penelitian menunjukkan bahwa terdapat empat saluran 
pemasaran beras dengan saluran terbanyak pada saluran 3 sebesar 53,3\%. Saluran satu merupakan saluran dengan margin pemasaran terendah, akan tetapi tidak bisa secara langsung disimpulkan bahwa saluran sartu merupakan saluran yang paling efisien. Margin pemasaran tertinggi dalam saluran pemasaran beras di tingkat penggilingan padi sedang/ besar dan terendah di tingkat pedagang besar. Nilai MPI pedagang pengumpul 2,00; penggilingan padi sedang/besar 2,32; pedagang besar 1,47; dan pedagang pengecer 1,75. Hasil perbandingan angka MPI pada tiap lembaga pemasaran menunjukkan penggilingan padi sedang/besar memiliki dominasi dalam pemasaran beras di Kabupaten Sragen. Perhitungan analisis korelasi 0,952 menunjukkan hubungan yang "sangat kuat" antara harga di tingkat penggilingan padi dengan harga di tingkat konsumen akhir. Berdasarkan analisis efisiensi pemasaran melalui MPI dan integrasi pasar diperoleh bahwa pemasaran beras di Kabupaten Sragen sudah terintegrasi dan efisien. Saran penelitian ini adalah adanya analisis mengenai pemasaran beras di daerah lain yang menjadi tujuan pemasaran beras untuk penggilingan padi atau pedagang beras di Kabupaten Sragen.

Kata Kunci: Beras, Efisiensi Pemasaran, Indeks Monopoli, Integrasi Pasar.

\section{INTRODUCTION}

National rice production is supported by the rice crop centers (granaries) production such as West Java, Central Java, East Java, North Sumatra, and South Sulawesi. These five provinces contribute for a major part in the national rice. The rice productivity in these five provinces is almost equal to the national productivity (Kusnadi et al., 2011). Central Java is the third largest rice producer province after East and West Java provinces. Harvested area of rice in Central Java continues to increase. Harvested area in Central Java in 2012 was $1,773,558 \mathrm{Ha}$ to $1,913,391 \mathrm{Ha}$ in 2016 . The average rice productivity in Central Java Province reached 56.90 quintals/ha. Sragen in one of rice producer in Central Java which became one of the centers of rice production. Harvested area of rice in Sragen was 93,994 Ha with the production of 611,710 tons. Sragen rice productivity reached 65.08 quintals/ha.
Marketing is one of the most essential subsystems to assure the success of farming. Marketing classified as good when it is efficient. However, rice marketing tends to be less efficient because it usually has a long marketing chain which affects product quality and the rate and prices of marketing margin, both of a farm level and consumer level. The shorter the marketing channel, the greater the profits as compared to the long marketing channels. It is due to more marketing agencies involved, this causing great price discrepancy between the price paid by consumers and received by farmers (Erzal et al., 2015).

The amount of marketing margin is often used as the operational efficiency indicator of marketing channels. The margin is influenced by marketing costs. High margins consider several things such as the use of new technologies that increase production costs, production 
specialization that leads to increased transportation costs, the usefulness of time in agricultural products that increase storage and processing costs, consumer's tendency towards products, and wage increases (Ika Novita Sari, 2012). The efforts to increase production should be followed by an effective and efficient marketing system to motivate farmers as producers. In addition to aspects of production, marketing is an important component in creating community accessibility to rice (Saragih and Tinnaprila, 2015). Rice production improvement program will not work effectively if the marketing system is inefficient. Marketing should be oriented to customer satisfaction and provide benefits to farmers, traders, processors and marketing institutions involved. In terms of decision making, farmers must have sufficient market information. They should also gain knowledge on the advantages and disadvantages of different channels and marketing strategies (Sultana, 2012).

In the free trade period, rice marketing patterns did not change significantly. The custom of selling their grain through the collecting traders was still shared by farmers. Marketing institutions such as KUD and BULOG which were expected to be more efficient did not work properly. No wonder if the grain and rice marketing channels remained inefficient as those in the previous period (Mardianto et al., 2005). The rice marketing chain in Sragen
Regency starts from small rice mill to consumable rice, then rice is processed by medium/large rice mill with a polisher machine to whiten rice. Rice from medium/ large rice mill is sent to large wholesalers to be marketed to local or outside markets in Sragen Regency region to the final consumer.

There are two types of rice produced in Sragen Regency: organic and semi organic rice. Marketing of organic rice in Sragen Regency is distributed by farmer groups. The weakness of the marketing of rice in Sragen Regency is the lack of promotional activities, the less target of organic rice distribution, the lack of market information, high shipping cost, and high production cost. Along with the increase of healthy lifestyles, well-educated people and income levels, stakeholders should streamline the rice distribution channels and determine the high quality of rice to people who are educated and high incomed. It is a priority in the rice marketing strategy in Sragen Regency (Lutfi, 2017). Thus, it is necessary to calculate the margin between rice milling to final consumer to determine the rice marketing efficiency in Sragen Regency.

Based on the previous research "Efficiency of Rice Distribution between Margokaton Village and Yogyakarta", there are five types of traders involved in rice marketing: harvesting contractors, collectors, rice milles, large collectors, 
and retailers. The main role of harvesting contractors is to harvest rice, collectors and millers handle drying and milling. Large collectors deliver rice from the study area to retailers in Yogyakartan markets and the retailers sell the rice to consumers. Rice millers are the most noncompetitive market when compared to others by MPI 4.92 (Jamhari and Yonekura, 2003). Previous research have a large number of marketing agencies involved in rice marketing, it is affected on the rice marketing efficiency.

This research aims to determine the rice marketing channel, marketing margin, and the marketing efficiency in Sragen Regency. The efficiency of rice marketing in this study is measured through the calculation of index monopoly (MPI) and market integration. The measurement about efficiency of rice marketing in Sragen can be references to stakeholders to understand the role and contribution of each marketing agencies.

\section{METHODS}

Data were obtained from direct interviews of 30 small rice mills with proportional random sampling in five districs of Sragen Regency, based on prepared questionnaires to browse its marketing channels. Secondary data were obtained from related institutions: Central Bureau of Statistics (BPS) and Agriculture Department of Sragen Regency.
This research was conducted in April to May 2018. The rice marketing channels in Sragen Regency could be traced using snowball sampling method on large rice mills, medium rice mills, wholesalers, collecting traders, and retailers. The data were collected using snowball sampling method which was a type of sampling that begins from a small group asked to appoint the next sample and so on, thus the sample grew larger like a snowball. The starting point in this research was the small rice millers.

To identify rice marketing channel in Sragen Regency, the descriptive analysis was employed through survey and interview. Afterwards, every marketing channel passed from small rice mill level to final consumer level was analyzed.

To calculate the marketing margin of rice, the below equation is used:

$$
\mathrm{M}=\mathrm{Pr}-\mathrm{Pf}
$$

$\mathrm{M}=$ Marketing Margin

$\operatorname{Pr}=$ Prices at the Consumer Level

$\mathrm{Pf}=$ Prices at the Rice Miller Level

The market structure as indicated by the monopoly index (MPI). The monopoly index (MPI) is one way of measuring marketing efficiency based on the performance of each marketing agency. The monopoly index (MPI) is a simplification of the Lerner Index. The marketing institution's competition level are (Jamhari and Kuntadi, 2012): 


$$
\mathrm{MPI}=\frac{\mathrm{m}}{\mathrm{Cv}}
$$

$\mathrm{M}=$ Marketing Margin

$\mathrm{Cv}=$ Variable Cost

A higher MPI value indicates the monopoly or dominance of the marketing agency in the marketing chain. The MPI above 1 indicates that the marketing agency has implemented the marketing function efficiently. The MPI below 1 indicates that the marketing agency has not implemented the marketing function efficiently.

To determine the price relationship between consumer level and rice miller level, market integration with correlation pearson product moment was measured (Swastika and Sumaryanto, 2012):

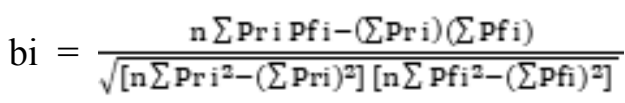

$\mathrm{bi}=$ Correlation Coefficient

$\operatorname{Pr}=$ Average Price of the Reference Market (Consumer)

$\mathrm{Pf}=$ Average Price of Initial Market Rate (Producer)

$\mathrm{n}=$ Number of Samples

The score of correlation coefficient determines the strong/weak relationship between price in producer market and price in the consumer market. If the correlation coefficient (bi) $=1$, it means that there is perfect price integration between producer and consumer market level. The correlation coefficient of 0.75-0.99 indicates a very strong integration. A score of 0.5-0.74 indicates a strong integration, 0.25-0,49 indicates a medium integration, and a score 0,01-0,24 indicates a very week integration. However, if the correlation coefficient (bi) $=0$, it shows an imperfect price integration.

\section{RESULTS AND DISCUSSION Rice Marketing Channel}

The three marketing functions are exchange, physical, and facility. The exchange function is an activity that facilitates the transfer of property rights of goods and services marketed. Physical function is all actions related to goods and services that cause the use of place, form and time. Function facilities are all measures aimed at facilitating the exchange activities that occur between producers and consumers (Downy and Erickson, 1992).

Market participants who were directly involved in rice marketing process are:

1. Small rice millers as rice producers, processing grain into rice. Small rice millers perform an exchange function (purchasing grain and rice sales), physical functions (grain storage, grain processing and rice transportation), and facility's function (risk and financing).

2. Collecting traders, collecting rice from a small rice mills to sell to medium/ large rice mills. Traders performs an exchange of function (buying and selling of rice), physical functions (transportation of rice), and facility functions (risk and financing). 
Medium/large rice millers, processing rice (polishing) to increase the selling value of rice processed by wholesalers who sell it to retailers inside and outside Sragen Regency. The third channel is the most demanded by respondents, which about $53.3 \%$. This is because the processed products of medium/ large rice mills had undergone the final polishing process making it more attractive to the final consumers. The fourth channel is the longest channel. About $13.3 \%$ of respondents use this channel because collecting traders facilitated conveyances to carry rice from small rice mills to large rice mills. It is the trader who facilitate transportation to carry rice from small rice mills to medium/large rice mills.

3. small rice mills. The functions performed by medium/large rice mills are the exchange functions (buying and selling of rice), physical functions (storage, processing, and transport of rice), and facility functions (standardization and grading, risk coverage, and financing).

4. Wholesalers, traders who market the rice in Sragen Area and outside. Wholesalers perform an exchange function (buying and selling of rice), physical functions (transporting rice), and facility functions (risk and financing).

Retailers act as a rice marketing agency that sells rice throughout the area of Sragen Regency. Retailers perform the functions of exchange (purchase and sale of rice), physical functions (storage and transportation of rice), as well as the function of facilities (grading).

Based on Figure 1 and Table 1, in the first channel, small rice millers as rice producers sell directly to existing retailers

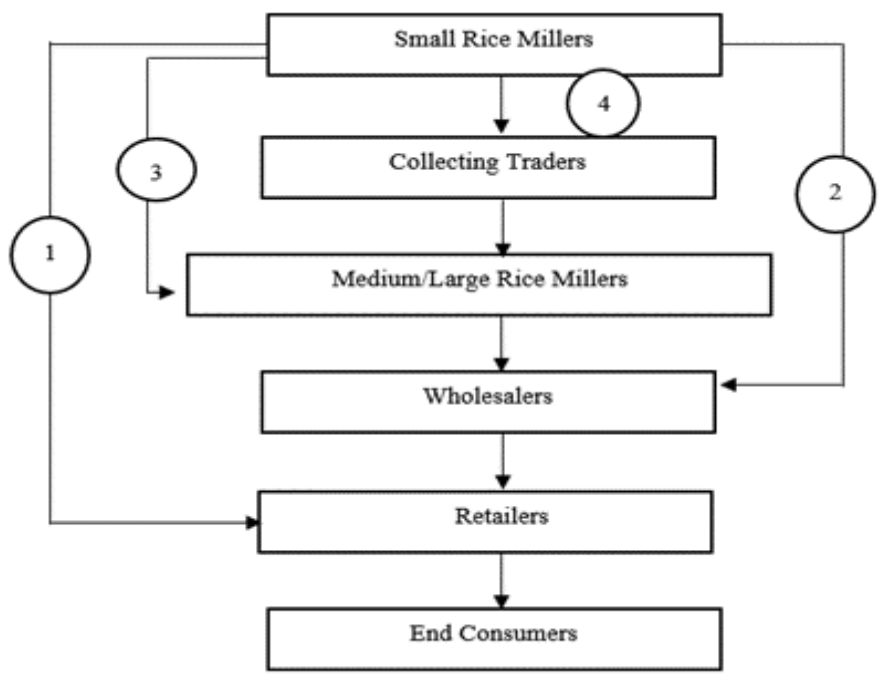

Figure 1. Rice Marketing Channel in Sragen Regency 
Table 1. Distribution of Rice Marketing Channel in Sragen Regency

\begin{tabular}{|c|c|c|c|}
\hline Channel & Pattern & Amount & Percentage \\
\hline 1 & small rice mill $\rightarrow$ retailer $\rightarrow$ final consumer & 2 & 6,7 \\
\hline 2 & $\begin{array}{l}\text { small rice mill } \rightarrow \text { wholesalers } \rightarrow \text { retailers } \rightarrow \text { final } \\
\text { consumers }\end{array}$ & 8 & 26,7 \\
\hline 3 & $\begin{array}{l}\text { small rice mill } \rightarrow \text { medium/large rice mills } \rightarrow \\
\text { wholesalers } \rightarrow \text { retailers } \rightarrow \text { final consumers }\end{array}$ & 16 & 53,3 \\
\hline \multirow[t]{2}{*}{4} & $\begin{array}{l}\text { small rice mill } \rightarrow \text { collecting traders } \rightarrow \text { medium/large } \\
\text { rice mill } \rightarrow \text { wholesalers } \rightarrow \text { retailers } \rightarrow \text { final consumers }\end{array}$ & 4 & 13,3 \\
\hline & AMOUNT & 30 & 100 \\
\hline
\end{tabular}

Source: Primary Analysis, 2018

in the central market or local market in their respective areas to be distributed to the final consumer. The first channel is the shortest channel. In the second channel, small rice millers firstly sell rice to

\section{Rice Marketing Margin}

One of the objectives of marketing margin analysis is to obtain marketing efficiency. The marketing efficiency indicated by the amount of profit is received by each marketer. In the first and second channels rice do not pass the medium/ large rice mill, rice are not polished, so the rice does not go through the process of polishing. On the third and fourth channel pass medium/large rice mill, so the rice has been passing the polishing, grading and sorting process that more attractive for the the final consumers.

The rice marketing pattern has been segmented between rice for middle to upper for middle to upper and low income consumers. Upper middle income consumers will generally buy rice in
Table 2. The Monopoly Index of Rice Marketing on Channel 1 in Sragen Regency

\begin{tabular}{lc}
\hline Cost per Kg & Retailers \\
\hline Average Purchase Price & 8,500 \\
VARIABLE COST & \\
- Transportation & 100 \\
- Depreciation & 42,5 \\
- Wage Sorters & 100 \\
- Packing & 25 \\
- Processing & 0 \\
Total Variable Cost & $\mathbf{2 6 7 . 5}$ \\
Average Profit & 232.5 \\
Average Selling Price & 9,000 \\
Marketing Margin -i & 500 \\
MPI & $\mathbf{1 . 8 7}$ \\
\hline
\end{tabular}

Source: Primary Data Analysis, 2018

specific places that selling rice with certain attributes, such as rice colour, taste, and others. On the other hand, the lower middle income people will generally go to traditional markets which generally distribute rice with lower middle quality. Two factors causing differences within rice prices are (a) the difference in the amount of rice availability that rice is sent from the surplus area to the deficit area; and (b) differences in people's preferences and purchasing power that the rice with 
good quality is sent to the consumer area with higher purchasing power and taste, in exchanged with rice of lower quality and rice (Mardianto et al., 2005).

The first channel is the shortest channel with the lowest marketing margin, but it is inapporopiate to conclude that the first channel is the most efficient channel. It is essential to calculate the costs and benefits of each marketing agency activity involved in rice marketing to know the structure of marketing margin based on the marketing cost component of each marketing actor. It is in line with Sinaga et al., (2014) stating that marketing efficiency should take into account existing marketing functions, costs, and product attributes.

\section{Marketing Efficiency}

The monopoly index (MPI)

Marketing margin analysis used to determine the distribution of marketing

Table 3. The Monopoly Index of Rice Marketing on Channel 2 in Sragen Regency

\begin{tabular}{lrr}
\hline \multicolumn{1}{c}{ Cost per Kg } & Wholesalers & \multicolumn{2}{c}{ Retailers } \\
\hline Average Purchase Price & 8,300 & 8,800 \\
VARIABLE COST & & \\
- Transportation & 200 & 100 \\
- Depreciation & 83 & 44 \\
- Wage Sorters & 0 & 100 \\
- Packing & 50 & 25 \\
- Processing & 0 & 0 \\
Total Variable Cost & $\mathbf{3 3 3}$ & $\mathbf{2 6 9}$ \\
Average Profit & 167 & 131 \\
Average Selling Price & 8,800 & 9,200 \\
Marketing Margin -i & 500 & 400 \\
MPI & $\mathbf{1 . 5 0}$ & $\mathbf{1 . 4 9}$ \\
\hline
\end{tabular}

Source: Primary Data Analysis, 2018

Table 4. The Monopoly Index of Rice Marketing on Channel 3 in Sragen Regency

\begin{tabular}{lrrr}
\hline Cost per Kg & $\begin{array}{c}\text { Medium /Large } \\
\text { Rice Mills }\end{array}$ & Wholesalers & Retailers \\
\hline Average Purchase Price & 8,200 & 9,500 & 10,000 \\
VARIABLE COST & & & \\
- Transportation & 200 & 200 & 100 \\
- Depreciation & 120 & 95 & 50 \\
- Wage Sorters & 0 & 0 & 100 \\
- $\quad$ Packing & 80 & 50 & 25 \\
- Processing & 160 & 0 & 0 \\
Total Variable Cost & $\mathbf{5 6 0}$ & $\mathbf{3 4 5}$ & $\mathbf{2 7 5}$ \\
Average Profit & 740 & 155 & 225 \\
Average Selling Price & 9,500 & 10,000 & 10,500 \\
Marketing Margin -i & 1,300 & 500 & 500 \\
MPI & $\mathbf{2 . 3 2}$ & $\mathbf{1 . 4 5}$ & $\mathbf{1 . 8 2}$ \\
\hline
\end{tabular}

Source: Primary Data Analysis, 2018 
margin that consist of cost and profit from every activity of marketing institution in rice marketing. Marketing efficiency cannot only be seen from the value of marketing margin. The marketing channels will cause margin rate, marketing costs, different profits, fair share of profit among actors in marketing which is determined by marketing efficiency (Jumiati et al., 2013).

The comparison of monopoly index (MPI) in each marketing institution shows that medium/large rice mills dominate rice marketing in Sragen Regency. The medium/ large rice mills are mostly rice markets outside of Sragen Regency such as Jakarta,
Bandung, Yogyakarta and Surakarta since the majority of people in Sragen Regency especially in rice producing area already have sufficient rice stock for household consumption so that they rarely buy rice. Rice consumers in Sragen Regency generally are residents in Sragen urban areas who are not involved in agricultural activities or food stalls sellers who buy rice through rice traders in Bunder Market of Sragen as rice market for consumers in Sragen city area. The calculation of the monopoly index (MPI) on each channel are:

The comparison of monopoly index (MPI) in each marketing channels shows

Table 5. The Monopoly Index of Rice Marketing on Channel 4 in Sragen Regency

\begin{tabular}{lrrrr}
\hline Cost per Kg & $\begin{array}{c}\text { Collecting } \\
\text { Traders }\end{array}$ & $\begin{array}{c}\text { Medium /Large } \\
\text { Rice Mills }\end{array}$ & Wholesalers & Retailers \\
\hline Average Purchase Price & 8,000 & 8,200 & 9,500 & 10,000 \\
VARIABLE COST & & & & \\
$\quad-\quad$ Transportation & 100 & 200 & 200 & 100 \\
- Depreciation & 0 & 123 & 95 & 50 \\
$-\quad$ Wage Sorters & 0 & 0 & 0 & 100 \\
- Packing & 0 & 80 & 50 & 25 \\
- Processing & 0 & 160 & 0 & 0 \\
Total Variable Cost & $\mathbf{1 0 0}$ & $\mathbf{5 6 3}$ & $\mathbf{3 4 5}$ & $\mathbf{2 7 5}$ \\
Average Profit & 100 & 737 & 155 & 225 \\
Average Selling Price & 8,200 & 9,500 & 10,000 & 10,500 \\
Marketing Margin -i & 200 & 1,300 & 500 & 500 \\
MPI & $\mathbf{2 . 0 0}$ & $\mathbf{2 . 3 1}$ & $\mathbf{1 . 4 5}$ & $\mathbf{1 . 8 2}$ \\
\hline
\end{tabular}

Source: Primary Data Analysis, 2018

Table 6. The Monopoly Index of Rice Marketing on Channel 1-4 in Sragen Regency

\begin{tabular}{lcccc}
\hline Channel & $\begin{array}{c}\text { Collecting } \\
\text { Traders }\end{array}$ & $\begin{array}{c}\text { Medium /Large } \\
\text { Rice Mills }\end{array}$ & Wholesalers & Retailers \\
\hline Channel 1 & - & - & - & 1.87 \\
Channel 2 & - & - & 1.50 & 1.49 \\
Channel 3 & - & 2.32 & 1.45 & 1.82 \\
Channel 4 & 2.00 & 2.31 & 1.45 & 1.82 \\
\hline Average & $\mathbf{2 . 0 0}$ & $\mathbf{2 . 3 2}$ & $\mathbf{1 . 4 7}$ & $\mathbf{1 . 7 5}$ \\
\hline
\end{tabular}

Source: Primary Data Analysis, 2018 
that medium/large rice mills dominate the rice marketing in Sragen Regency. The result is similiar with previous research by Jamhari and Yonekura (2003) stating that milling is an institution having the highest monopoly index value. In rice marketing in Sragen Regency, the difference of monopoly index (MPI) calculation between each marketing institution on rice milling is not too high. It indicates that there is an efficient marketing activity in each rice marketing channel in Sragen Regency.

\section{Market Integration}

Market integration using price correlation analysis to determine the strong/ weak relationship between rice price in producer market (rice milling) and price in the consumer market (final consumer). The result of correlation between price at rice milling and price at rice consumer with $\alpha=$ 0,01 (1\%) indicate that the Pearson Product Moment correlation is 0.952 , it means there is a significant relationship between price at the level rice producers with prices at the consumer level of rice. The correlation relationship is "very strong", indicated by the correlation value approaching to +1 with $\mathrm{p}$-value/sig. equal to $0.00<0.05$, it can be concluded that there is a very significant relationship between the two variables. A positive sign indicates that the correlation between the two variables is positive (proportional), it means that a price increase in the rice milling rate corresponds to an increase in the price at the level of the final consumer. The two-way relationship between the price at the rice mill level and the price at the consumer level indicates an integrated rice market in Sragen Regency. Based on the overview of the marketing channel, the average final consumer of rice in Sragen Regency obtains rice through retailers in the market or in the nearest stalls through channel one, that is small rice mill $\rightarrow$ the retailer $\rightarrow$ the final consumer so that the marketing chain is relatively short, as shown by rice market integration in Sragen Regency.

\section{CONCLUSION AND SUGGESTION}

Based on the four rice marketing channels in Sragen Regency, the majority

Table 7. Output Correlation of Price Analysis at Rice Milling Level and Rice Consumer Level in Sragen Regency

\begin{tabular}{llcc}
\hline & & Price at Rice Mill & Price at Rice Consumer \\
\hline Price at Rice Milling & Pearson Correlation & 1 & $.952^{* *}$ \\
& Sig. (2-tailed) & & .000 \\
& $\mathrm{~N}$ & 30 & 30 \\
Price at Rice Consumer & Pearson Correlation & $.952^{* *}$ & 1 \\
& Sig. (2-tailed) & .000 & 30 \\
& $\mathrm{~N}$ & 30 & 30 \\
\hline
\end{tabular}

**. Correlation is significant at the 0.01 level (2-tailed).

Source: Primary Data Analysis, 2018 
channel is the third channel, that is through small rice mill $\rightarrow$ medium/large rice mill $\rightarrow$ wholesaler $\rightarrow$ retailer $\rightarrow$ final consumer, it because the processed product from small rice mill should be processed further through the final polishing step to be more attrack the final consumer.

The monopoly index value (MPI) of collecting traders is $2.00 ; 2.32$ for medium/ large rice mills; 1.47 for wholesalers; and 1.75 for retailers. The comparison of monopoly index (MPI) in each marketing institution shows that the medium/large rice mills have dominated rice marketing in Sragen Regency. The calculation of correlation analysis about 0.952 indicates a very strong integration between the price in the rice mills and the rice consumers.

Based on the marketing efficiency analysis using monopoly index (MPI) and market integration shows that marketing of rice in Sragen Regency has been integrated and efficient. It because only a small proportion of the population in Sragen Regency buy rice for daily consumption, especially in urban areas that are not based in the agricultural sector. Generally, the agriculture-based workers obtain their daily consumed rice from their own rice harvests or from working in the fields by grinding the grain to a small mill around it.

Most of the rice produced by rice mills in channel thee and four is sold in other regions. It is because the processed products of medium/large rice mills have undergone the final plosihing process, making it more attractive to the final customers. Thus, it is privotal to have futher analysis on rice marketing in other areas for rice marketing in rice mills or rice traders in Sragen Regency. However, in channel one and two, rice is sold directly to existing retailers in the central market or local market. It is necessary to spesialize rice marketing of rice in channel three and four to sell it outside, and channel one and two for inside Sragen Regency areas.

It is done to trace the areas dominated by rice from Sragen. To lower the cost and improve efficient marketing systems of the products of rural areas, it is necessary to involve goverment participation as an investor and stabilizer of the surrounding economy. Participation of all stakeholders is needed to achieve efficiency in rice marketing.

\section{REFERENCES}

Downy and Erickson. (1992). Manajemen Agribisnis. Jakarta: Erlangga.

Erzal, M. F., Taslim and Masdar, A. S. (2015). Analisis Saluran, Margin, dan Efisiensi Pemasaran Itik Lokal Pedaging. Jurnal Unpad, 2, 1-12.

Ika Novita Sari, R. W. (2012). Analisis Efisiensi Pemasaran Jagung di Provinsi Nusa Tenggara Barat. Journal of Institut Pertanian Bogor, 2(2), 191-210. 
Jamhari and Kuntadi, E. B. (2012). Efisiensi

Pemasaran Cabai Merah melalui Pasar Lelang Spot di Kabupaten Kulonprogo, Yogyakarta. Jurnal Sosial Ekonomi Pertanian, 1(April), 95-101.

Jamhari and Yonekura, H. (2003). Efficiency of Rice Distribution Between Margokaton Village and Yogyakarta. Agro Ekonomi, 259-281.

Jumiati, Elly; Darwanto, Dwidjono Hadi; Hartono, S. M. (2013). Analisis Saluran Pemasaran dan Marjin Pemasaran Kelapa Dalam di Daerah Perbatasan Kalimantan Timur. Jurnal Agrifor, XII(1), 1-10. https://doi.org/1412 6885

Kusnadi, N., Tinaprilla, N., Susilowati, S. H. and Purwoto, A. (2011). Rice Farming Efficiency Analysis in Some Rice Producing Areas in Indonesia. Jurnal Agro Ekonomi, Volume 29, 25-48.

Lutfi, Z. (2017). Strategi Pemasaran Beras Organik pada Kelompok Tani Sri Makmur di Kabupaten Sragen. Tesis Institut Pertanian Bogor.

Mardianto, S., Suprianta, Y. and Agustin, N. K. (2005). Dinamika Pola Pemasaran
Gabah dan Beras di Indonesia. Forum Penelitian Agro Ekonomi, 23(70), 116-131.

Saragih, E. and Tinnaprila, N. (2015). Sistem Pemasaran Beras di Kecamatan Cibeber, Kabupaten Cianjur. Jurnal Forum Agribisnis, 5(1), 1-24.

Sinaga, V. R., Fariyanti, A. and Tinaprilla, N. (2014). Analisis Rantai Nilai Pemasaran Kentang Granola di Kecamatan Pengalengan Kabupaten Bandung Jawa Barat. In Prosiding PERHEPI (pp. 191-209). IPB International Convention Center, Bogor.

Sultana, A. (2012). Rice Marketing in Bangladesh : From the Perspective of Village Study at Cox 's Bazar District. African Journal of Agricultural Research, 7(45), 5995-6004. https:// doi.org/10.5897/AJAR12.1840

Swastika, D. and Sumaryanto. (2012). Rice Supply Chain in Indonesia: The Cases in Wst Java, West Kalimantan, and South Kalimantan Provinces. Bunga Rampai Rantai Pasok Komoditas Pertanian Indonesia, I, 11-43. 